\title{
POLYPLOIDY AND GENOME SIZE VARIATION IN PHLOX NANA (POLEMONIACEAE) FROM THE PECOS PLAINS OF NEW MEXICO AND THE DAVIS MOUNTAINS OF WEST TEXAS, U.S.A.
}

\section{Jamie Ladner}

Kansas State University

Herbarium and Division of Biology

Manhattan, Kansas 66506, U.S.A.

\section{Alan Prather}

Michigan State University

Herbarium and Department of Plant Biology

East Lansing, Michigan 48823, U.S.A.

alan@msu.edu

\author{
Mark H. Mayfield \\ Kansas State University \\ Herbarium and Division of Biology \\ Manhattan, Kansas 66506, U.S.A. \\ markherb@ksu.edu
}

\author{
Carolyn J. Ferguson \\ Kansas State University \\ Herbarium and Division of Biology \\ Manhattan, Kansas 66506, U.S.A. \\ ferg@ksu.edu
}

ABSTRACT

Polyploidy is conspicuous in the genus Phlox, and some species exhibit variation in ploidy levels, or cytotypic variation. Diploid, tetraploid and hexaploid populations of P. nana occur across parts of the species distribution in the southwestern United States and northern Mexico. A recent study highlighted two areas for which ploidy level inferences were challenging: a population on the Pecos Plains of New Mexico ("Caprock") and the Davis Mountains region of West Texas. Plants in these areas were sampled and chromosome counts and flow cytometry methods were used to assess ploidy levels and genome sizes. Homoploid variation in genome size was unambiguously documented: the genome size of tetraploid plants from the Davis Mountains was significantly larger than that of plants from Caprock. The general condition of larger genome sizes for plants in the Davis Mountains explains previous difficulty in determining ploidy levels within the region. Most plants at the Caprock population appeared to be tetraploid $(2 n=28)$, but chromosome counts revealed variants, including some putative pentaploids. Within the Davis Mountains region, both diploid $(2 n=14)$ and tetraploid $(2 n=28)$ cytotypes were documented, with a parapatric distribution. Overall, this study clarifies patterns of cytotypic diversity in P. nana, highlights an example of infraspecific, homoploid genome size variation, and contributes to a framework for ongoing evolutionary investigation in this study system.

\section{RESUMEN}

La poliploidía es notable en el género Phlox, y algunas especies exhiben variación en sus niveles de ploidía, o variación citotípica. Poblaciones diploides, tetraploides y hexaploides de P. nana ocurren en varias partes de la distribución de la especie en el suroeste de los Estados Unidos y el norte de México. Un estudio reciente destacó dos áreas para las cuales las inferencias del nivel de ploidía eran difíciles: una población en Pecos Plains de Nuevo México ("Caprock") y la región de Davis Mountains en el oeste de Texas. Se tomaron muestras de plantas en estas áreas y se usaron recuentos de cromosomas y citometría de flujo para evaluar los niveles de ploidía y los tamaños del genoma. Se documentó sin ambigüedad la variación homoploide en el tamaño del genoma: el tamaño del genoma de las plantas tetraploides de Davis Mountains fue significativamente mayor que el de las plantas de Caprock. La condición general de tamaños de genoma mayores para las plantas en Davis Mountains explica la dificultad previa en la determinación de los niveles de ploidía dentro de la región. La mayoría de las plantas de la población de Caprock parecían ser tetraploides $(2 n=28)$, pero los recuentos de cromosomas revelaron variantes, incluyendo algunos pentaploides putativos. Dentro de la región de Davis Mountains, se documentaron citotipos diploides $(2 n=14)$ y tetraploides $(2 n=28)$, con una distribución parapátrica. En general, este estudio clarifica los patrones de la diversidad citotípica en P. nana, destaca un ejemplo de variación infraespecífica del tamaño del genoma homoploide, y contribuye a una estructura para la investigación evolutiva en curso en este sistema de estudio.

KEY WoRDS: cytotype, chromosome count, flow cytometry, genome size

\section{INTRODUCTION}

Polyploidy, or genome doubling, is a common phenomenon in plants and has occurred throughout angiosperm evolutionary history (Otto \& Whitton 2000; Wendel \& Doyle 2005; Parisod et al. 2010; Soltis et al. 2014). Species exhibiting cytotypic variation provide opportunities to investigate polyploidy at fine scales relative to aspects of diversity including geography/ecology, morphology and genetics. To this end, development of 
diverse, natural study systems, with careful documentation of patterns of cytotypic variation, improves our ability to investigate the consequences of polyploidy for diversity (reviews by Soltis et al. 2007, 2010, 2014, 2016; Ramsey \& Ramsey 2014).

Phlox L. (Polemoniaceae) is a predominantly North American genus of mostly perennial herbs (Wherry 1955; Locklear 2011), and is an excellent system for studies of polyploidy and diversity (e.g., Fehlberg \& Ferguson 2012a; Chansler et al. 2016). A recent study by Wright et al. (2016) examined polyploidy in P. nana Nutt. across its distribution in mountainous areas of West Texas, much of New Mexico, southeastern Arizona, and parts of northern Chihuahua, Mexico. Diploid, tetraploid and hexaploid cytotypes were documented by chromosome counts, and flow cytometry methods were used to infer ploidy levels for populations across the distribution (Wright et al. 2016). Wright et al. were able to infer ploidy level for the vast majority of sites studied ( $97 \%$ of 76 sites; with 417 individuals examined). The authors found a complex pattern of cytotypic variation, with diploid and tetraploid populations occurring commonly across most of the species distribution and occasional hexaploid populations in Mexico and western New Mexico. Ongoing work on P. nana includes morphological, ecological, phylogenetic and population genetic study within the framework of cytotypic variation (CJF, LAP, and S. Fehlberg, unpubl.). Yet Wright et al. (2016) noted two particular areas wherein interpretation of their data was challenging, and urged further study.

In general, Wright et al. (2016) found populations to be uniform for cytotype, with the exception of rare triploids (four individuals from two otherwise diploid sites). However, one population on the Pecos Plains of eastern New Mexico yielded unusual flow cytometry data (site 10 of Wright et al., 2016; herein referred to as "Caprock"). Most individuals in the Caprock population had inferred genome sizes within the range typical for tetraploids in the study (Fig. 4 and Appendix 1 of Wright et al. [2016]; mean tetraploid genome size 14.89 picograms [pg]), but a single individual had a very large genome size (2C DNA content nearly $24 \mathrm{pg}$, just above the range of measurements for hexaploids of $P$. nana), raising the question of a mixed cytotype population with tetraploid and hexaploid individuals. Mixed ploidy populations are rare in Phlox but have been documented (e.g., Fehlberg \& Ferguson 2012a; Chansler et al. 2016). A tetraploid mitotic chromosome count was obtained for the Caprock population; however, intriguingly, it exhibited an additional chromosome beyond the tetraploid number $(2 n=28+1$ [based on a Phlox base chromosome number of $x=7$ ]; Wright et al., Fig. 3c). Furthermore, of the 13 chromosome counts reported by Wright et al., counts for four sites included supernumerary chromosomes (from 1-4 additional chromosomes or fragments of chromosomes). Such occasional detection of additional chromosomes is not unusual in cytological studies of Phlox (e.g., Meyer 1944; Smith \& Levin 1967; Worcester et al. 2012; Zale 2014). The authors referred to these as "B" chromosomes, but cautioned that information regarding origin and potential functionality of such chromosomes in Phlox is lacking. In general, Wright et al. suggested that presence of additional chromosomes could explain relatively high genome size measurements.

A more challenging situation, in terms of inferring ploidy levels, was posed by sites in the Davis Mountains, which contain isolated pine-oak woodlands surrounded by high deserts in West Texas (Jeff Davis Co.; Bataineh et al. 2007). Wright et al. sampled from ten sites in the Davis Mountains (sites 65-75; Wright et al. 2016), and made one tetraploid and two diploid chromosome counts (one of the latter included an additional chromosome fragment). Flow cytometry measurements from the Davis Mountains resulted in a general pattern of larger genome sizes relative to diploid and tetraploid populations sampled from across the distribution of the species, making interpretation difficult; the authors were generally cautious in their inferences of ploidy levels for the region, and two sites were considered "unclassified" with respect to ploidy level (Wright et al. 2016). Wright et al. hypothesized that genome size could be higher in the region (i.e., that their findings reflect genome size variation - aside from chromosome number variation-across the species distribution of P. nana) and/or that additional chromosomes could be a factor. They noted the need for additional chromosome counts from the region as well as additional flow cytometry work (ideally using an internal standard from a larger genome to improve measurement precision; see Suda et al. 2007; Wright et al. 2016) to resolve patterns of cytotypic variation. 
The present work is a focused study of P. nana from Caprock and the Davis Mountains. We used chromosome counts linked to estimates of genome size from flow cytometry to (1) test whether genome size variation occurs among tetraploids of P. nana, (2) characterize ploidy at sites for which it could not be reliably inferred in the study of Wright et al. (2016), and (3) document the distribution of cytotypes in the Davis Mountains region of West Texas. Such investigation not only advances Phlox as a study system, but also provides insights regarding the utility and potential challenges of applying flow cytometry data to infer ploidy levels across natural populations.

\section{MATERIALS AND METHODS}

\section{Sampling}

The Caprock population on the Pecos Plains of New Mexico previously studied by Wright et al. (site 10 of Wright et al., 2016; Table 1) was visited during peak flowering in May of 2016. Leaf material was collected from 13 individuals and placed in silica gel and stored at room temperature. Inflorescences of the same plants were enclosed with lightweight mesh bags labeled with individual identifiers; bags were retrieved several weeks later, following dehiscence of fruits, to obtain seeds when present. Thus, seeds could be matched with leaf material of maternal (seed) parent plants. In addition, numerous seeds were available from a previous "bulk" collection from the Caprock site (the same collection of seeds from which the chromosome count reported by Wright et al., 2n=28+1B, was made; Wright et al. 2016).

Nine sites in the Davis Mountains were included in the present study: five previously studied sites and four additional sites (Wright et al. 2016; Table 1). Field work was conducted in May and June of 2015, and leaf material (generally from at least five individuals per population) and seeds were obtained in the same manner described above for the Caprock population. A map of studied sites in the Davis Mountains was produced in the statistics package R (version 3.4.1; R Core Team 2017) using the packages ggplot2 (version 2.2.0; Wickham 2009) and ggmap (version 2.7; Kahle and Wickham 2013), using terrain map tiles (Stamen Maps, https://stamen.com/, accessed 22 August 2017).

\section{Chromosome Counts}

To obtain material for mitotic chromosome counts, seeds were germinated on moist paper towels in petri plates in a refrigerator (approx. 2-4 weeks). Following initial germination, seeds were removed to the bench top at room temperature. When root tips were $1-3 \mathrm{~cm}$ in length, they were excised, placed in water and placed on ice for approximately 24 hours. The root tips were then transferred to a 3:1 solution of $95 \%$ ethanol:glacial acetic acid to fix dividing cells. Fixed root tips were stained with $1 \%$ acetocarmine for 3-4 hours, heated and squashed for observation under a light microscope. Counts were conducted at $400 \times$ magnification and images were made using an Olympus DP71 camera.

\section{Flow Cytometry}

Flow cytometry methods followed the same approach of previous studies of Phlox from our lab (e.g., Fehlberg \& Ferguson 2012a, 2012b; Worcester et al. 2012; Chansler et al. 2016; Wright et al. 2016). An internal standard with a relatively large genome size was sought to enable improved precision of measurements for tetraploid plants (see Doležel et al. 2007; see also discussion by Wright et al. 2016). Based on preliminary study, Lathyrus sativus L. was selected as an internal size standard because its peak did not overlap with any of the tetraploid material for the present study. Seeds of L. sativus were obtained from the USDA (accession number PI 170470) and grown in the greenhouse.

Samples of silica gel-dried leaves of P. nana were co-chopped with freshly dried L. sativus leaves in a flow cytometry buffer (Davison et al. 2007; modified from Bino et al. 1993), filtered through $30 \mu \mathrm{m}$ nylon mesh filter, vortexed, and placed on ice. Samples were then centrifuged and the liquid decanted; the resulting nuclei were treated with RNAse and stained with propidium iodide (BioSure) before being placed on ice for 1-3 hours prior to runs on a Becton Dickinson FACSCalibur in the Flow Cytometry lab of the College of Veterinary Medicine, Kansas State University. Histograms were analyzed using the program CellQuest (Becton Dickinson). Each sample was run to include at least 10,000 events (nuclei) and histograms were checked to ensure clear 
sample and standard peaks with coefficient of variation (CV) values below 5\% (Galbraith et al. 1997; Doležel \& Bartoš 2005). 2C DNA values (in pg) were calculated as the sample/standard ratio multiplied by the estimated genome size for the internal standard (Doležel \& Bartoš 2005). The genome size used for L. sativus was 13.69 (the mean 2C DNA value for studies in the RGB Kew plant DNA C-values database based on flow cytometry with propidium iodide; Bennett and Leitch 2012; based on Nandini et al. 1997; Ali et al. 2000). Statistics were performed in the statistics package R and ggplot 2 was used to produce boxplots.

RESULTS

\section{Chromosome Counts}

Ten mitotic chromosome counts were made for the Caprock population (site Na4x_10), one from a seed of a marked individual, and nine from seeds from the bulk seed collection (Table 1). Three of the chromosome counts were tetraploid ( $2 n=28$; Table 1; Fig. 1c). However, numerous counts from the bulk seed collection revealed additional chromosomes beyond the tetraploid number, with numbers ranging from one to eight (Table 1; Fig. 2a-c). Given the base chromosome number of $x=7$, a pentaploid mitotic figure would consist of 35 chromosomes: four of the Caprock counts may thus be interpreted as pentaploid (Table 1; Figs. 2b, c).

Fifteen chromosome counts were made for plants from the Davis Mountains, chiefly from seeds from unique, marked individuals (Table 1). Counts were obtained from seven of the nine sites (1-4 counts per site; Table 1). Both diploid and tetraploid chromosome counts were made, and most counts did not exhibit additional chromosomes beyond the expected complement (a single count from site Na4x_67 revealed two additional chromosomes beyond the tetraploid number; $2 n=28+2$; Fig. 2d; Table 1).

\section{Flow Cytometry Data, and Linking to Chromosome Counts}

Flow cytometry data were obtained for 13 individuals from the Caprock population; and from all nine sites from the Davis Mountains (typically five individuals per site; 41 individuals total; Table 1). Figure 3 presents boxplots for these data, arranged generally by genome size and region. Individuals from two sites in the Davis Mountains had the smallest genome size estimates with an average of $9.31( \pm 1.11) \mathrm{pg}$, and diploid chromosome counts confirmed diploids in these sites (Table 1; Fig. 3, left; Fig. la, b); plants at these sites are inferred to be diploids. Individuals from the Caprock population had an average genome size of $16.30( \pm 0.96) \mathrm{pg}(16.05[ \pm$ 0.27] pg excluding the outlier data point for individual E; Table 1; Fig. 3, center). Given the similarity in genome sizes for individuals from this site, and tetraploid chromosome counts for seeds from some individuals from Caprock (Table 1), these are generally inferred to be tetraploids (although individual E could be a plant with additional chromosomes, even a pentaploid). Finally, most individuals from the Davis Mountains (from the remaining seven sites in the region) had large genome sizes with an average of $19.77( \pm 1.05) \mathrm{pg}$, and tetraploid chromosome counts confirmed tetraploids at most of these sites; these individuals are inferred to be tetraploids (Table 1; Fig 3, right). Overall, using flow cytometry data linked to chromosome counts, ploidy level was assigned for all studied sites (including sites previously unclassified by Wright et al., one of which was resolved as diploid and one as tetraploid; Table 1).

\section{Genome Size Variation}

Variation in genome size among tetraploid individuals was clearly evidenced, with genome sizes for the Caprock plants being significantly smaller than those for tetraploids from the Davis Mountains region based on a Student's T-test ( $<<0.001 ;$ Fig. 3). The average genome size for Caprock individuals was $16.30( \pm 0.96)$ pg; while the average genome size for all individuals from tetraploid sites in the Davis Mountains was 19.77 ( \pm 1.05) pg (see Table 1). The particular genome size estimates of Wright et al. (2016) are not directly comparable to data herein because of use of different internal standards; however, findings herein follow the general trend noted by Wright et al. of larger genome sizes in plants from the Davis Mountains. For example, Wright et al. found genome sizes of diploids and tetraploids from across the distribution of P. nana to peak at 6.50-7.49 pg and $15.00-15.49 \mathrm{pg}$, respectively, while their data for plants from the Davis Mountains resulted in higher picogram values (for both ploidies; Appendices 2 and 3 of Wright et al. [2016]). 
TABLE 1. Samples and ploidy level data for Phlox nana from the Caprock population on the Pecos Plains of New Mexico and the Davis Mountains region of West Texas. Site codes are unique and link to previous and ongoing research in this study system (e.g., Wright et al. 2016). Information for each site includes specimen voucher information, general locality, related summary information from Wright et al. (2016) where applicable, chromosome count information, genome size data based on flow cytometry, and inferred ploidy level(s).

\begin{tabular}{|c|c|c|c|c|c|c|}
\hline & & & Wright et al. (2016): site & & & \\
\hline Site code & $\begin{array}{l}\text { Herbarium } \\
\text { voucher }^{1}\end{array}$ & General locality & $\begin{array}{l}\text { no., chromosome count, } \\
\text { inferred ploidy }{ }^{2}\end{array}$ & Chromosome count $^{3}$ & $\begin{array}{l}\text { Genome } \\
\text { size }(p g)^{4}\end{array}$ & $\begin{array}{l}\text { Ploidy } \\
\text { level(s) }\end{array}$ \\
\hline
\end{tabular}

\section{Caprock population, Chaves Co., NM:}

$\begin{array}{lll} & & \\ & & \\ & & \\ \text { Na4x_10 } & \text { S. Fehlberg Plains se } \\ \text { of Roswell; } & \\ & 33.023579 \mathrm{~N}, & 10 ; 2 n=28+\mathrm{B} ; 4 \mathrm{x}+/(6 \mathrm{x} \text { ? } \\ & 50814-1 & 103.80096 \mathrm{~W}\end{array}$

Davis Mountains region, Jeff Davis Co., TX:

$\begin{array}{ll}\mathrm{S}_{\mathrm{E}}: 2 n=28 & \text { B: } 16.15 \\ \text { bulk: } 2 n=28 \text {; Fig. 1c } & \text { C: } 15.54 \\ \text { bulk: } 2 n=28 & \text { D: } 15.66 \\ \text { bulk: } 2 n=28+1 & \text { E: } 19.38 \\ \text { bulk: } 2 n=28+4 & \text { F: } 16.01 \\ \text { bulk: } 2 n=28+5 \text {; Fig. 2a } & \text { G: } 15.84 \\ \text { bulk: } 2 n=28+7^{*} & \text { H: } 15.97 \\ \text { bulk: } 2 n=28+7^{*} \text {; Fig 2b } & \text { J: } 16.28 \\ \text { bulk: } 2 n=28+7^{*} \text {; Fig 2C } & \text { K: } 16.39 \\ \text { bulk: } 2 n=28+8^{*} & \text { L: } 16.18 \\ & \text { M: } 15.96 \\ & \text { N: } 16.30\end{array}$

A: 16.30

D: 15.66

E: 19.38

$\mathrm{H}: 15.97$

: 16.18

$\mathrm{N}: 16.30$

A: 19.71

B: 19.97

C: 19.42

D: 18.67

A: 19.36

D: 20.32

G: 19.23

I: 19.22

K: 19.80

$\mathrm{S}_{\mathrm{A}}: 2 n=28$; Fig 1e A: 19.41

$\mathrm{S}_{\mathrm{D}}: 2 n=28 \quad \mathrm{H}: 19.97$

$\mathrm{S}_{\mathrm{F}}: 2 n=28$

I: 19.26

K: 19.87

M: 19.69

A: 7.55

E: 9.28

F: 9.71

H: 7.08

J: 9.28

$\mathrm{S}_{\mathrm{B}}: 2 n=28$

bulk: $2 n=28$; Fig. $1 f$

B: 19.51

Boy Scout Rd, Little
Aguja Canyon; 74;-; unclassified

$30.81471 \mathrm{~N}$

103.93597 W

ghs: 20.02

A: 21.81

C: 21.34

D: 23.96

E: 20.27

G: 19.16

A: 19.35

B: 19.03

Boy Scout Rd, Little

Aguja Canyon; (N/A, new site)

(no seeds germinated)

C: 18.58

D: 18.63

E: 20.32
$4 x^{7}$

$4 x, 5 x^{5}$

$4 x$

$4 x$

$4 x$

$2 x$

$4 x$

$4 x$ 
TABLE 1. continued

\begin{tabular}{|c|c|c|c|c|c|c|}
\hline Site code & $\begin{array}{l}\text { Herbarium } \\
\text { voucher }^{1}\end{array}$ & General locality & $\begin{array}{l}\text { Wright et al. (2016): site } \\
\text { no., chromosome count, } \\
\text { inferred ploidy }{ }^{2}\end{array}$ & Chromosome count $^{3}$ & $\begin{array}{l}\text { Genome } \\
\text { size }(p g)^{4}\end{array}$ & $\begin{array}{l}\text { Ploidy } \\
\text { level(s) }\end{array}$ \\
\hline $\mathrm{Na} 2 \mathrm{x} \_89$ & AP 3917 & $\begin{array}{l}\text { Limpia Canyon; } \\
30.64967 \mathrm{~N}, \\
103.80899 \mathrm{~W}\end{array}$ & (N/A, new site) & $\begin{array}{l}\mathrm{S}_{\mathrm{D}}: 2 n=14 ; \text { Fig } 1 \mathrm{~b} \\
\mathrm{~S}_{\mathrm{D}}: 2 n=14\end{array}$ & $\begin{array}{l}\text { A } 10.11 \\
\text { B: } 9.69 \\
\text { C: } 10.07 \\
\text { G: } 10.02 \\
\text { H: } 10.31\end{array}$ & $2 x$ \\
\hline $\mathrm{Na} 4 \mathrm{x} \_90$ & AP 3923 & $\begin{array}{l}\text { Madera Canyon } \\
\text { Roadside Park; } \\
30.70682 \mathrm{~N}, \\
104.10398 \mathrm{~W}\end{array}$ & (N/A, new site) & (no seeds germinated) & $\begin{array}{l}\text { A: } 18.98 \\
\text { B: } 19.97 \\
\text { C: } 19.40 \\
\text { D: } 19.38 \\
\text { E: } 19.28\end{array}$ & $4 x$ \\
\hline
\end{tabular}

${ }^{1}$ Herbarium specimen vouchers are housed at KSC except in the case of 50814-1 (Caprock), which is housed at DES.

${ }^{2}$ Of the sites studied, six were also studied by Wright et al. (2016), and four, all in the Davis Mountains, are new to the present study. Where applicable, information from the Wright et al. study is noted: site number, chromosome count, inferred ploidy (Wright et al. 2016, Appendix 1). Note that Wright et al. obtained chromosome counts for two of the sites ( $N a \_4 \times 10$ and Na_4x67; their study included both mitotic [denoted by $2 \mathrm{n}=)$ ] and meiotic [ $\mathrm{n}=$ ] counts). The present study includes both sites Wright et al. denoted as "unclassified" as to ploidy level (Na2x_73 and Na4x_74; Wright et al. 2016).

${ }^{3} \mathrm{Phlox}$ has a base chromosome number of $\mathrm{x}=7$, and expected diploid and tetraploid mitotic chromosome numbers are thus $2 \mathrm{n}=14$ and $2 n=28$, respectively. Mitotic chromosome counts are herein reported, with additional chromosomes beyond the tetraploid number indicated following " + " (i.e., with no interpretation, here, of potential cases of B chromosomes, unlike Wright et al. [2016]; see text for discussion). Three counts, indicated with asterisks, are interpreted as pentaploid; see text for discussion. All counts were made on root tips of germinating seeds, and seeds were obtained from individual plants, often also measured for flow cytometry, or from a bulk seed collection. In cases for which seeds were obtained from individually identified plants, " $S$ " denotes seed and subscript capital letters denote individual identifiers for seed parent plants; thus $S_{A}$ denotes a seed that came from plant $A$. Where seeds came from a bulk seed collection, "bulk" is indicated, with no notation regarding parent plant.

${ }^{4}$ Genome size estimates (2C DNA content) in picograms (pg) for individuals studied. Capital letters are individual identifiers for field collected plants. In one case, a seed was grown past the early germination stage in the greenhouse, and flow cytometry was conducted using leaf material from the seedling; that value is indicated by "ghs" and is included in the table but not in Fig. 3 (flow cytometry data for field collected samples). Flow cytometry work was conducted concurrently with chromosome count work, and there was not a perfect match between which individuals were run for flow cytometry and those for which seeds, when available, yielded successful chromosome counts. ${ }^{5}$ We infer tetraploid and pentaploid cytotypes for site Na4x_10 based on data from the present study (although Wright et al. [2016] may well have sampled a hexaploid individual; see text for discussion).

${ }^{6}$ Very few plants could be sampled at site Na4x_74 in 2015, but a new site in close proximity, Na4x_88, was additionally studied. In addition, a small bulk seed collection was made at site $\mathrm{Na4x} 74$ at the time that individual mesh bags were retrieved.

${ }^{7} \mathrm{An}$ anomalous result was obtained during chromosome count work for site Na4x_74, and a labeling error is suspected. Counts were made for two different seeds that were attributed to seed parent A. One of those yielded cell squashes showing $2 n=14$ (diploid), while the other one was $2 n=28$ (tetraploid). No plants from the site yielded flow cytometry measurements indicative of diploids (nor did the findings of Wright et al. [2016] suggest the possibility of diploids at this site). Few plants were sampled here for the present study, however numerous plants were sampled from nearby site Na4x_88 and all were inferred to be tetraploid. We treat the anomalous diploid count as an error, and do not list any counts for the seeds of individual $\mathrm{A}$ in the data table.

\section{DISCUSSION}

The most striking finding from this study of P. nana is the genome size variation among tetraploids from the Caprock population versus the Davis Mountains region: Davis Mountains tetraploids are approximately 3 pg larger in genome size than individuals at Caprock (Fig. 3). Moreover, the average genome size for Davis Mountains tetraploids is about double that for Davis Mountains diploids (Fig. 3), supporting the notion that $P$. nana may have a larger genome size generally in the Davis Mountains region (see Wright et al. [2016]). While Wright et al. had less precise flow cytometry data and they viewed their Davis Mountains data to be confounding, it is now clear that genome size-aside from ploidy level variation—was the key factor contributing to their difficulty in inferring ploidy levels within the Davis Mountains. Within-species genome size variation at the homoploid level (i.e., in the absence of polyploidy) has been detected in both plant and animal systems, and is generally attributed to variation in the amount of repetitive DNA, such as transposable elements and 


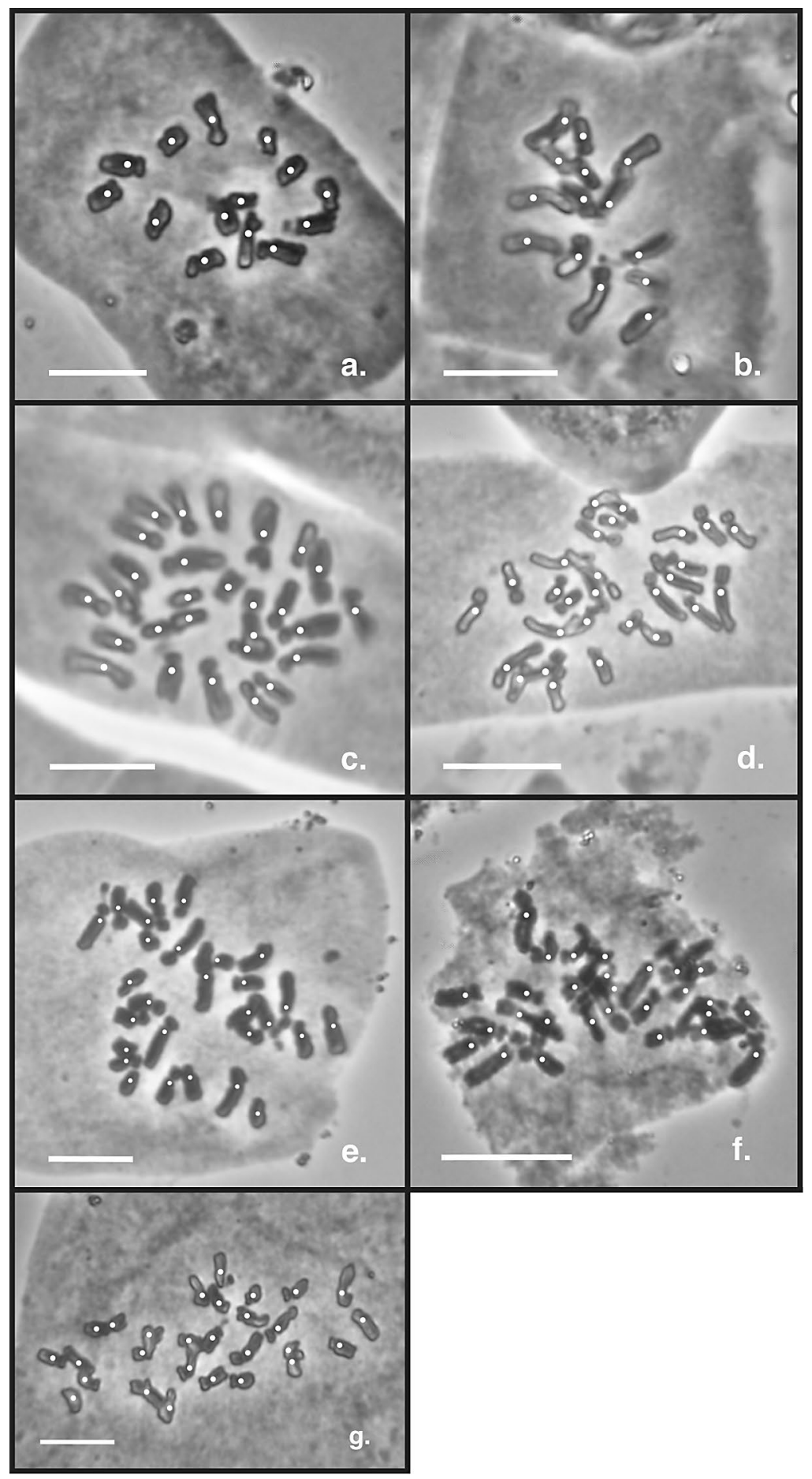

Fig. 1. Examples of mitotic chromosome counts for Phlox nana: diploid counts $(2 n=14 ; \mathrm{a}, \mathrm{b})$, and tetraploid counts $(2 n=28 ; \mathrm{c}, \mathrm{d}, \mathrm{e}, \mathrm{f}, \mathrm{g})$. The scale bar represents $10 \mu \mathrm{m}$ and chromosomes are indicated with small white markers. a) Site Na2x_73;2n=14.b) Site Na2x_89;2n=14.c) Site Na4x_10;2n=28. d) Site Na4x_67; $2 n=28$. e) Site Na4x_68; $2 n=28$. f) Site Na4x_74; $2 n=28$. g) Site Na_4x78; $2 n=28$. 


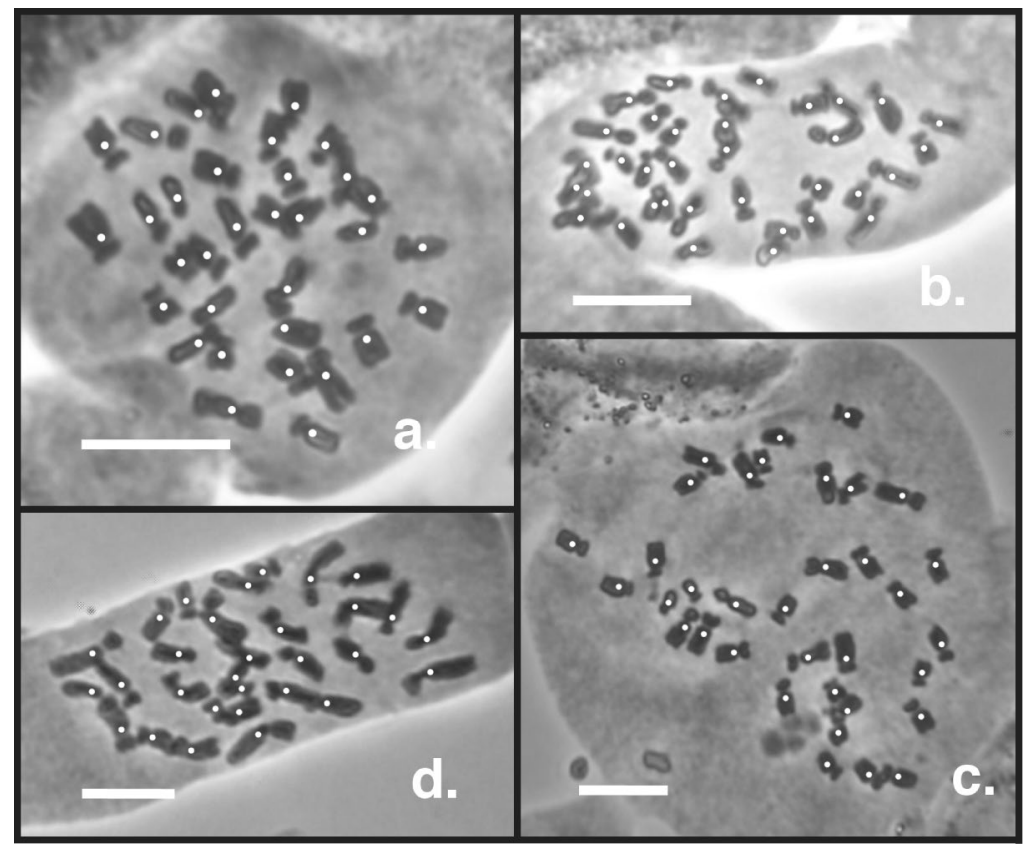

Fig. 2. Examples of mitotic chromosome counts for Phlox nana exhibiting additional chromosomes beyond the tetraploid ( $2 n=28)$ number. The scale bar represents $10 \mu \mathrm{m}$ and chromosomes are indicated with small white markers. a) Site Na4x_10; $2 n=28+5$. b) Site Na4x_10; $2 n=28+7$. c) Site Na4x_10; $2 n=28+7$. d) Site Na4x_67; $2 n=28+2$. Counts of $2 n=35$ or more (frames b, c) are considered pentaploid; see text for discussion.

ribosomal DNA (review by Biémont 2008). Some studies have detected a correlation between genome size and ecological factors such as altitude and temperature (e.g., in Zea mays, Díez et al. 2013; see also review by Knight et al. 2005). Taken together with the Wright et al. (2016) study, which documented cytotypic diversity across the broad distribution of the species, our work indicates that genome size of $P$. nana tetraploids is increased in the Davis Mountains relative to tetraploid populations in the species overall. This is a clear example of infraspecific genome size variation at the homoploid level in Phlox, and will have interesting implications for ongoing research. For example, in conjunction with genetic studies investigating origins of polyploids in $P$. nana, it may provide evidence for a local origin of polyploidy in the Davis Mountains.

The present study resolves ploidy levels for sites that were problematic in a previous study of cytotypic variation in P. nana (Wright et al. 2016). Individuals at Caprock are chiefly tetraploid: flow cytometry measurements of sampled individuals showed low variation in genome size estimates, and we made three strictly tetraploid chromosome counts (2n=28). Wright et al. (2016) also inferred most Caprock individuals to be tetraploid based on flow cytometry, but they reported a single, unusually large value, which they considered to indicate a possible hexaploid. While we did not detect any plants with genome sizes we would interpret to indicate hexaploids (see below), each study sampled individuals haphazardly: there may be (or may have been) a hexaploid individual that simply was not sampled by us. Intriguingly, we made additional chromosome counts from the bulk seed collection of Wright et al. that revealed four apparent pentaploids (Table 3; as well as several counts considered to be tetraploid with additional chromosomes, representing either B chromosomes or aneuploidy [see Wright et al. 2016]). Since seeds in the bulk collection were not linked to individual parents, we do not know whether the seeds yielding these chromosomes counts came from one or multiple individuals. To our knowledge, this is the first report of pentaploid chromosome counts in Phlox, although pentaploids have been inferred based on flow cytometry data for a population of P. woodhousei (Fehlberg \& Ferguson 2012a). Overall, our assessment of the Caprock population based on the present study is 4x, 5x (Table 1). 


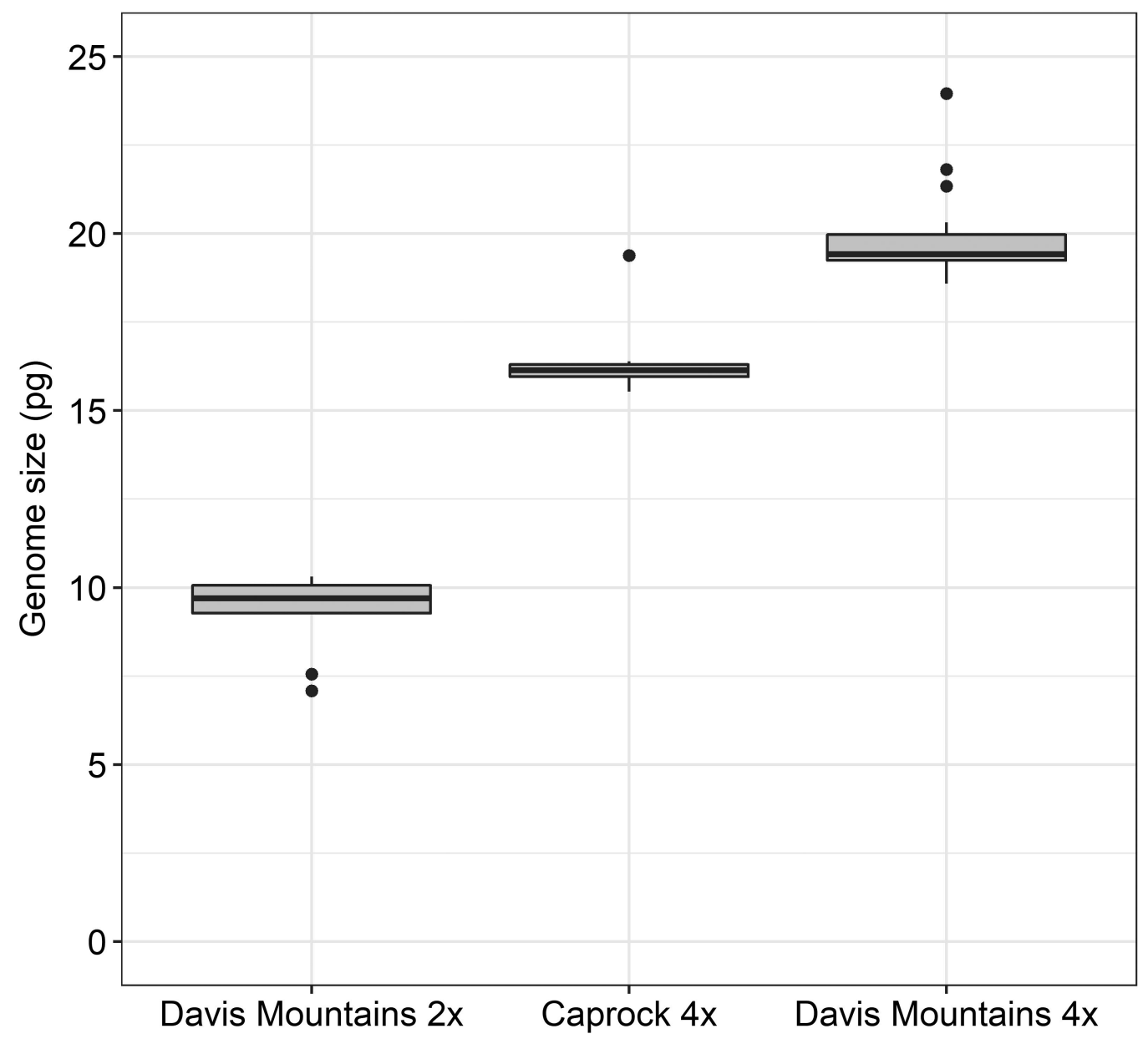

FIG. 3. Boxplot comparison of genome size estimates for individuals of Phlox nana from the Caprock population and the Davis Mountains region based on flow cytometry. Individual values are listed in Table 1 by site. Plants from diploid sites in the Davis Mountains (left) have the smallest genomes. A significant difference in genome size among tetraploids from different areas is illustrated by the data for Caprock (center) and the Davis Mountains sites (right). Genome size estimates for tetraploids from the Davis Mountains (right) are approximately double the size of those of diploids from the Davis Mountains (left).

Within the Davis Mountains, we confirmed the presence of both diploid and tetraploid populations, and resolved ploidy levels for all sites (including those unclassified and tentatively assigned by Wright et al. [2016]). In terms of geography, the diploid and tetraploid cytotypes occur parapatrically in the Davis Mountains (Fig. 4; see also Wright et al. 2016). Our two studied diploid sites occurred in Limpia Canyon along Texas highway 17 northeast of Fort Davis (Na2x_73 and Na2x_89, Table 1). Previously reported diploid chromosome counts from the Davis Mountains also come from sites in Limpia Canyon (counts for two sites by Wright et al. [2016]; and a count reported by Eater [1967]). Sites sampled outside of Limpia Canyon are tetraploid, including sites near Fort Davis (Na4x_67 and Na4x_68; approx. 15 km southwest of the closest Limpia Canyon sites; Wright et al. 2016), sites to the west in the vicinity of McDonald Observatory (Na4x_65 and Na4x_78) and farther west in Madera Canyon (Na4x_90), and sites to the north in Aguja Canyon (Na4x_74 and Na4x_88; Table 1). The only previously published tetraploid count for the region came from a site also included in the present study (Na4x_67, in Davis Mountains State Park near Fort Davis; Wright et al. 2016). Resolution of cytotypic patterns 


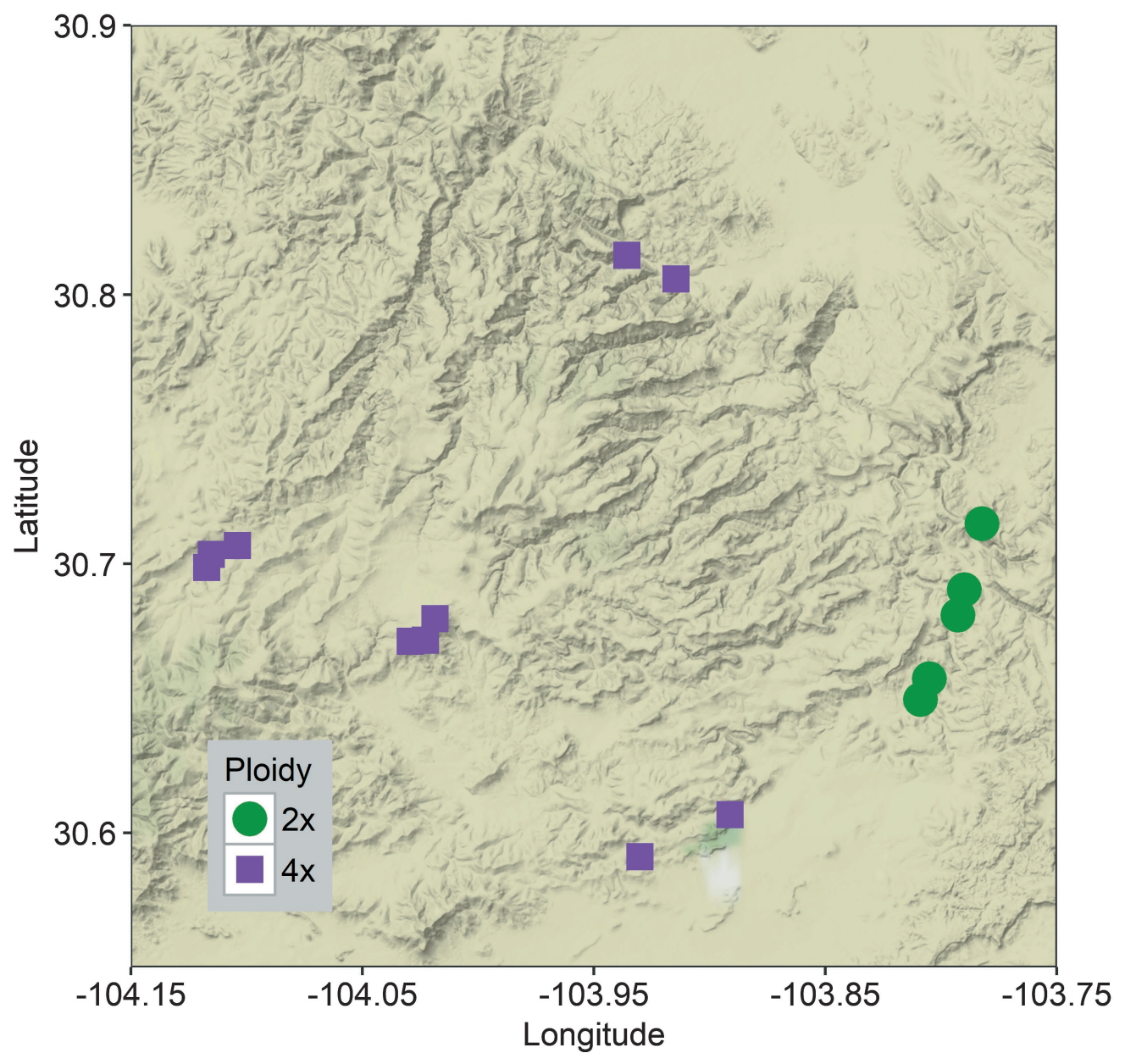

FIG. 4. Distribution of Phlox nana study sites within the Davis Mountains. Sites from the present study (Table 1) and additional sites of Wright et al. (2016) are included.

at this fine geographic scale relative to Wright et al. (2016) sets the stage for investigating correlates of polyploidy and ecology, and exploring polyploid formation in the region.

Overall, this study advances P. nana as an excellent experimental system for ongoing investigation of polyploidy and diversity. In light of patterns of cytotypic variation in this system, data from morphological, genetic and ecological studies will contribute to our understanding of how polypoidy affects aspects of diversity. More broadly, the finding of homoploid genome size variation highlights a potential challenge in using flow cytometry to infer ploidy levels across natural populations, and underscores the value of linking flow cytometry data to chromosome counts in such systems to ensure rigorous inferences of ploidy levels (Doležel \& Bartoš 2005; Suda et al. 2007).

\section{ACKNOWLEDGMENTS}

We are grateful to Shannon Fehlberg, Kevin Fehlberg, Matt Chansler and Amy Perez for field assistance, Mark Ungerer for providing greenhouse space for growth of plants, the KSU Flow Cytometry lab for technical assistance, and the KSU Wheat Innovation Center for use of microscope facilities. Mark Fishbein, Brittany 
Sutherland, and one anonymous reviewer provided valuable comments that improved the manuscript. Stamen Map terrain tiles used under Creative Commons license CC BY 3.0, https://creativecommons.org/licenses/ by/3.0/) and map data from OpenStreetMap contributors by Open Database License 1.0 (https://opendatacommons.org/licenses/odbl/). We acknowledge the herbaria KSC, MSC, SRSC, TEX/LL and UTEP, and thank the following groups for collecting permits: Texas Parks and Wildlife, Texas Highways, The Nature Conservancy, McDonald Observatory (University of Texas at Austin). JL gratefully acknowledges support during Spring 2016 from the Undergraduate Research Program of the KSU College of Arts and Sciences, and during Summer 2016 from an NSF-REU supplement (to DEB-1258167). This research is supported by U.S.A. National Science Foundation (NSF) grants (DEB-1258167, DEB-1258005, and DEB-1258067). This project is supported by the United States Department of Agriculture (USDA) National Institute of Food and Agriculture and AgBioResearch. This is publication 18-099-J of the Kansas Agricultural Experiment Station.

\section{REFERENCES}

Ali, H.B.M., A. Meister, \& I. Schubert. 2000. DNA content, rDNA loci, and DAPI bands reflect the phylogenetic distance between Lathyrus species. Genome 43:1027-1032.

Bataineh, M.M., B.P. Oswald, A.L. Bataineh, K.W. Farkish, D.W. Coble, \& C.B. Edminster. 2007. Plant communities associated with Pinus ponderosa forests in the sky islands of the Davis Mountains, Texas. J. Torrey Bot. Soc. 134:468-478.

BennetT M.D. \& I.J. Leitch. 2012. Angiosperm DNA C-values database (release 8.0, Dec. 2012). Available at http://www.kew. org/cvalues/. Accessed August 2017.

BIÉMONT, C. 2008. Within-species variation in genome size. Heredity 101:297-298.

Bino, R.J., S. Lanteri, H.A. Verhoeven, \& H.L. KraAk. 1993. Flow cytometric determination of nuclear replication stages in seed tissues. Ann. Bot. 72:181-187.

Chansler, M.T., C.J. Ferguson, S.D. Fehlberg, \& L.A. Prather. 2016. The role of polyploidy in shaping morphological diversity in natural populations of Phlox amabilis (Polemoniaceae). Amer. J. Bot. 103:1546-1558.

Davison, J., A. TYAGI, \& L. ComAl. 2007. Large-scale polymorphism of heterochromatic repeats in the DNA of Arabidopsis thaliana. B.M.C. PI. Biol. 7:44.

Díez, C.M., B.S. Gaut, E. Meca, E. Scheinvar, S. Montes-Hernandez, L.E. Eguiarte, \& M.I. Tenaillon. 2013. Genome size variation in wild and cultivated maize along altitudinal gradients. New Phytol. 199:264-276.

DoležEL, J. \& J. BARToš. 2005. Plant DNA flow cytometry and estimation of nuclear genome size. Ann. Bot. 95:99-110.

DoležEl, J., J. Greilhuber, \& J. SudA. 2007. Flow cytometry and ploidy: applications in plant systematics, ecology and evolutionary biology. Wiley-VCH, Weinheim, Germany.

EATER, J.W. 1967. A systematic study of subsection Nanae of the genus Phlox. M.Sc. thesis, University of California, Santa Barbara, California, U.S.A.

Fehlberg, S.D. \& C.J. Ferguson. 2012a. Intraspecific cytotypic variation and complicated genetic structure in the Phlox amabilis-P. woodhousei (Polemoniaceae) complex. Amer. J. Bot. 99:865-874.

Fehlberg, S.D. \& C.J. Ferguson. 2012b. Intraspecific cytotype variation and conservation: an example from Phlox (Polemoniaceae). Calochortiana 1:189-195.

Galbraith, D.W., G.M. Lambert, J. Macas, \& J. DoležEl. 1997. Analysis of nuclear DNA and ploidy in higher plants. Curr. Protoc. Cytom. 7.6:1-22.

KaHLE, D. \& H. WICKHAM. 2013. ggmap: Spatial visualization with ggplot2. The R Journal 5: 144-161. Available at http:// journal.r-project.org/archive/2013-1/kahle-wickham.pdf.

KnIGHt, C.A., N.A. Molinari, \& D.A. Petrov. 2005. The large genome constraint hypothesis: evolution, ecology and phenotype. Ann. Bot. 95:177-190.

LOCKLEAR, J.H. 2011. Phlox: a natural history and gardener's guide. Timber Press, Portland.

MEYER, J.R. 1944. Chromosome studies of Phlox. Genetics 29:199-216.

Nandini, A.V., B.G. Murray, I.E.W. O’Brien, \& K.R.W. Hammett. 1997. Intra- and interspecific variation in genome size in Lathyrus (Leguminosae). Bot. J. Linn. Soc. 125:359-366.

Otтo, S.P. \& J. Whitton. 2000. Polyploid incidence and evolution. Ann. Rev. Genet. 34:401-437.

Parisod, C., R. Holderegger, \& C. Brochmann. 2010. Evolutionary consequences of autopolyploidy. New Phytol. 186:5-17.

R Core Team. 2017. R: A language and environment for statistical computing. R Foundation for Statistical Computing, Vienna, Austria. Available at https://www.R-project.org/. Accessed August 2017. 
Ramsey, J. \& T. Ramsey. 2014. Ecological studies of polyploidy in the 100 years following its discovery. Philos. Trans., Ser. B 369:20130352.

SмIтH, D.M. \& S.A. LeVIN. 1967. Karyotypes of eastern North American Phlox. Amer. J. Bot. 54:324-334.

Soltis, D.E., R.J.A. BugGS, J.J. Doyle, \& P.S. Soltis. 2010. What we still don't know about polyploidy. Taxon 59:1387-1403.

Soltis, D.E., P.S. Soltis, D.W. Schemske, J.F. Hancock, J.N. Thompson, B.C. Husband, \& W.S. Judd. 2007. Autopolyploidy in angiosperms: have we grossly underestimated the number of species? Taxon 56:13-30.

Soltis, D.E., C.J. VISGER, \& P.S. SoltIS. 2014. The polyploidy revolution then...and now: Stebbins revisited. Amer. J. Bot. 101:1057-1078.

Soltis, D.E., C.J. Visger, D.B. Marchant, \& P.S. Soltis. 2016. Polyploidy: pitfalls and paths to a paradigm. Amer. J. Bot. 103:1146-1166.

SudA, J., P. KRON, B.C. HusBAnd, \& P. TRÁvničEK. 2007. Flow cytometry and ploidy: applications in plant systematics, ecology and evolutionary biology. In J. Doležel, J. Greilhuber, and J. Suda, eds. Flow cytometry with plant cells: analysis of genes, chromosomes and genomes. Wiley-VCH, Weinheim, Germany. Pp. 103-130.

Wendel, J.F. \& J.J. Doyle. 2005. Polyploidy and evolution in plants. In: R.J. Henry, ed. Plant diversity and evolution: Genotypic and phenotypic variation in higher plants. CABI Publishing, Oxfordshire, U.K. Pp. 97-117.

Wherry, E.T. 1955. The genus Phlox. Morris Arbor. Monogr. 3:1-174.

WICKнам, H. 2009. ggplot2: Elegant graphics for data analysis. Springer-Verlag, New York, New York, U.S.A.

Worcester, L., M.H. MAyfield, \& C.J. Ferguson. 2012. Cytotypic variation in Phlox pilosa ssp. pilosa (Polemoniaceae) at the western edge of its range in the central United States. J. Bot. Res. Inst. Texas 6:443-451.

Wright, B.A., L.A. Prather, \& C.J. Ferguson. 2016. Polyploidy in Phlox nana (Polemoniaceae): diversity and distribution of cytotypes across a desert sky island region of North America. J. Bot. Res. Inst. Texas 10:45-63.

ZALE, P.J. 2014. Germplasm collection, characterization, and enhancement of eastern Phlox species. Ph.D. dissertation, The Ohio State University, Columbus, Ohio, U.S.A. 